\title{
Hubungan Antara Pengetahuan Dengan Efikasi Diri Penderita Tuberkulosis Paru
}

\section{Erni Herawati ${ }^{1}$, Okti Sri Purwanti ${ }^{2 *}$}

${ }^{1}$ Program Studi Ilmu Keperawatan Universitas Muhammadiyah Surakarta, Kartasura, 57162, Jawa Tengah, Indonesia.

2Departemen Keperawatan Medikal Bedah, Program Studi Ilmu Keperawatan Universitas Muhammadiyah Surakarta, Kartasura, 57162, Jawa Tengah, Indonesia.

*Korespondensi: Okti.Purwanti@ums.ac.id

\begin{abstract}
Abstrak: Tuberkulosis (TB) merupakan penyakit menular yang dapat menyerang berbagai organ, terutama paru-paru. Penanganan terhadap tingginya prevalansi TB harus dilakukan untuk mengendalikan penyakit TB Paru, salah satunya yaitu dengan pengobatan. Selain pengobatan untuk mencapai kesembuhan sangat penting bagi penderita TB Paru memiliki pengetahuan tentang penyakitnya dan memiliki efikasi diri yang tinggi. Tujuan penelitian ini untuk mengetahui hubungan antara pengetahuan dengan efikasi diri penderita TB paru. Jenis penelitian ini adalah kuantitatif dengan pendekatan cross sectional. Metode yang digunakan adalah non probability sampling. Populasi penelitian ini adalah penderita TB paru yang menjalani rawat jalan di Poliklinik TB BBKPM. Sampel yang digunakan adalah 72 responden dengan teknik pengambilan sampel accidental sampling. Instrumen adalah kuesioner pengetahuan dan efikasi diri yang telah diujicobakan pada 20 pasien TB paru. Analisis data non parametrik menggunakan uji koefisien korelasi Spearman rho dengan hasil menunujukkan sebagian besar pasien berada pada kategori pengetahuan cukup dan sebagian besar memiliki efikasi diri yang tinggi dengan nilai $\mathrm{p}=0,001<\alpha=0,05$ dan nilai korelasi Spearman sebesar 0.381. Simpulan yaitu adanya hubungan yang positif dan signifikan antara pengetahuan dengan efikasi diri penderita TB paru di BBKPM Surakarta.
\end{abstract}

Kata kunci: Pengetahuan, efikasi diri, tuberkulosis, kardiovaskuler, paru.

Abstract: Tuberculosis (TB) is a pulmonary infectious diseases that can attack the lungs. Handling of the high prevalence of $T B$ should be taken to control the disease Pulmonary $T B$, one of which is the treatment. In addition to treatment to achieve a cure is very important for patients with pulmonary TB have the knowledge about the disease and have a high self-efficacy. The purpose of this study was to determine the relationship between knowledge and self-efficacy pulmonary tuberculosis patients. This research is a quantitative research with cross sectional approach. The method used non-probability sampling. This research is pulmonary tuberculosis patients who underwent outpatient at Polyclinic BBKPM TB. The samples were 72 respondents with accidental sampling technique. The instrument was a questionnaire of knowledge and self-efficacy has been tested on 20 patients with pulmonary tuberculosis. Non-parametric data analysis using the Spearman rho correlation coefficient test with the results showed that most of the patients are in the category of enough knowledge and most have high selfefficacy with $p=0.001<\alpha=0.05$ and Spearman correlation value for 0381. Conclusion that the existence of a positive and significant relationship between knowledge and self-efficacy pulmonary tuberculosis patients in Surakarta BBKPM.

Keywords: Knowledge, self-efficacy, tuberculosis, cardiovasculer, lung 


\section{PENDAHULUAN}

Tuberkulosis merupakan penyakit menular yang dapat menyerang berbagai organ, terutama paruparu. TB diperkirakan sudah ada di dunia sejak 5000 tahun sebelum masehi. Kemajuan dalam penemuan dan pengendalian penyakit TB Paru sudah ada sejak 2 abad terakhir (Pusat data dan Informasi KEMENKES Republik Indonesia, 2015). Walaupun demikian, sebagian besar negara- negara di dunia belum berhasil mengendalikan penyakit TB. Angka kesakitan dan kematian akibat penyakit TB cenderung menetap dan meningkat (Widoyono, 2011).

WHO (2010) menunjukkan bahwa ada 22 negara dengan insiden terhadap TB (High Burden of TB Number) daya estimasi sebanyak 9,4 juta jiwa mengidap panyakit TB dan Indonesia menempati urutan kelima teratas. Total kejadian di Indonesia pada tahun 2009 mencapai 5000 dari total populasi 229.965 jiwa.

Departemen Kesehatan Republik Indonesia tahun 2007 melaporkan bahwa angka kematian akibat TB ini diperkirakan 95\% terjadi di negara yang sedang berkembang. Di Indonesia, Jawa Tengah merupakan salah satu propinsi yang menempati urutan kelima tertinggi prevalensi penyakit TB. Tahun 2012 prevalensi TB Paru sebesar 10,64\% per 100.000 penduduk (Dinas Kesehatan Provinsi Jawa Tengah, 2013).

Penanganan terhadap tingginya prevalansi TB tersebut harus dilakukan untuk mengendalikan penyakit TB Paru, salah satunya dengan pengobatan. Pengobatan penyakit TB dapat dilakukan selama enam sampai sembilan bulan dan diberikan dalam dua tahap yakni tahap awal dan tahap lanjutan (Kementrian Kesehatan RI, 2010). Untuk mencapai kesembuhan sangat penting bagi penderita TB Paru memiliki pengetahuan tentang penyakitnya (Aditama \& Aris, 2013). Pengetahuan tersebut dalam hal keteraturan, kelengkapan dan kepatuhan dalam minum Obat Anti Tuberkulosis (OAT). Sebaliknya, jika pengobatan tidak teratur dan kombinasi OAT yang tidak lengkap akan menimbulkan kegagalan pengobatan sehingga mengakibatkan Mycobacterium Tuberculosis menjadi kebal dan menimbulkan terjadinya kasus MDR (Multidrug Resistence) TB serta akan menjadi sumber penularan untuk orang lain (Anugerah, 2007).

Selain itu, untuk mencapai kesembuhan, penderita juga harus memiliki efikasi diri yang tinggi. Efikasi diri penderita yang rendah akan berakibat pada kegagalan pengobatan. Efikasi diri merupakan keyakinanindividu dalam mengelolah perilaku-perilaku tertentu untuk mencapai kesembuhan. Keyakinan diri penderita untuk sembuh dicapai salah satunya dari kognitif atau pengetahuan yang diberikan oleh petugas kesehatan melalui konseling (Hendiani, Sakti \& Widiyanti, 2013).

Berdasarkan data rekam medik BBKPM Surakarta jumlah penderita tuberkulosis pada tahun 2013 yaitu sebanyak 928 orang meningkat pada tahun 2014 menjadi 938 orang atau sebesar 1,06\%.

Studi pendahuluan yang dilakukan tanggal 19 Juni 2015 di BBKPM Surakarta, dengan melakukan wawancara terhadap lima pasien. Pernyataan tiap pasien tersebut adalah mereka sudah diberikan konseling di Poliklinik TB. Akan tetapi hanya tiga pasien diantaranya cukup mengetahui tentang penyakit TB paru yang meliputi: cara penularan, gejala, penatalaksanaan

pengobatan, pencegahan penularan serta mereka meyakini kesembuhan penyakitnya. Dua pasien lainya hanya mengetahuitentang cara pengobatan, penularan serta kurang yakin terhadap kesembuhan penyakitnya.

Berdasarkan paparan diatas dan mengingat pentingnya keyakinan diri (efikasi diri) yang berdampak pada kesembuhan penderita, sehingga membuat peneliti tertarik untuk meneliti "hubungan antara pengetahuan dengan efikasi diri pada penderita TB paru di BBKPM Surakarta".

\section{METODE}

Penelitian ini termasuk penelitian dengan jenis penelitian kuantitatif dengan mengunakan pendekatan cross sectional yaitumengobservasi serta dilakukan sekaligus pada saat bersamaan terhadap variabel independent yang termasuk faktor resiko dan variabel dependent yang termasuk faktor efek (Imron, 2010). Populasi dalam penelitian ini adalah penderita TB paru yang menjalani rawat jalan di Poliklinik TB BBPKM Surakarta yang masuk kriteria inklusi dan eksklusi, dengan jumlah sampel 72 responden. 
Pengambilan sampel mengunakan Accidental sampling. Instrumen dalam pengumpulan data yaitu kuesioner pengetahuan penderita TB Paru dan efikasi diri penderita TB Paru. Analisa data yang dilakukan adalah analisa deskriptif (Univariat) dengan tabel distribusi frekuensi dan analisis Bivariat dengan uji koefisien korelasi spearman rank (Rho).

HASIL

Tabel 1. Distribusi karakteristik responden

\begin{tabular}{|c|c|c|}
\hline Karakteristik & Frekuensi & Prosentase $(\%)$ \\
\hline \multicolumn{3}{|l|}{ Jenis kelamin } \\
\hline Laki-laki & 40 & $56 \%$ \\
\hline Perempuan & 32 & $44 \%$ \\
\hline \multicolumn{3}{|l|}{ Umur } \\
\hline$<55$ th & 68 & $94 \%$ \\
\hline$>55$ th & 4 & $6 \%$ \\
\hline \multicolumn{3}{|l|}{ Pendidikan } \\
\hline SD & 24 & $32 \%$ \\
\hline SMP & 22 & $30 \%$ \\
\hline SMA & 19 & $2 \%$ \\
\hline Perguruan Tinggi & 7 & $10 \%$ \\
\hline \multicolumn{3}{|l|}{ Pekerjaan } \\
\hline Tidak bekerja & 8 & $11 \%$ \\
\hline IRT & 4 & $6 \%$ \\
\hline Petani & 10 & $54 \%$ \\
\hline Wiraswasta & 39 & $6 \%$ \\
\hline Karyawan & 4 & $10 \%$ \\
\hline \multicolumn{3}{|l|}{ Lama Pengobatan TB } \\
\hline$<2$ bulan & 29 & $40 \%$ \\
\hline $3-6$ bulan & 43 & $60 \%$ \\
\hline \multicolumn{3}{|c|}{ Mendapat informasi pengobatan TB } \\
\hline Tidak pernah & 41 & $57 \%$ \\
\hline Pernah & 31 & $43 \%$ \\
\hline \multicolumn{3}{|c|}{ Sumber informasi pengobatan TB } \\
\hline Tidak mendapatkan & 41 & $57 \%$ \\
\hline Petugas kesehatan & 27 & $38 \%$ \\
\hline Lain-lain & 4 & $5 \%$ \\
\hline \multicolumn{3}{|c|}{ Mengalami stress saat pengobatan } \\
\hline Ya & 55 & $76 \%$ \\
\hline Tidak & 17 & $24 \%$ \\
\hline \multicolumn{3}{|c|}{$\begin{array}{l}\text { Mengetahui orang lain berhasil } \\
\text { dalam pengobatan TB }\end{array}$} \\
\hline Tidak pernah & 31 & $43 \%$ \\
\hline Pernah & 41 & $57 \%$ \\
\hline \multicolumn{3}{|c|}{$\begin{array}{l}\text { Mengetahui orang lain gagal } \\
\text { dalam pengobatan TB }\end{array}$} \\
\hline Tidak pernah & 63 & $87 \%$ \\
\hline Pernah & 9 & $13 \%$ \\
\hline
\end{tabular}

Tabel 1 menunjukkan bahwa mayoritas responden laki-laki (56\%), berusia $<55$ tahun (94\%), pendidikan SD (32\%), bekerja sebagai wiraswasta (54\%), menjalani pengobatan TB 3-6 bulan (60\%). 
Berdasarkan pengobatan TB menunjukkan sebagian besar menyatakan tidak pernah mendapat informasi pengobatan TB (57\%), kemudian responden yang pernah mendapat informasi pengobatan sebagian besar informasi berasal dari petugas kesehatan (38\%), dan sebagian besar tidak mengalami stress atau kecemasan (76\%), terdapat $57 \%$ mengetahui terdapat orang lain atau saudara yang mengalami keberhasilan pengobatan TB dan $14 \%$ responden pernah mengetahui terdapat orang lain atau saudara yang mengalami tidak berhasil dalam pengobatan TB.

Tabel 2. Distribusi frekuensi pengetahuan

\begin{tabular}{ccc}
\hline Pengetahuan & Frekuensi & Prosentase (\%) \\
\hline Kurang & 14 & $19 \%$ \\
Cukup & 33 & $46 \%$ \\
Baik & 25 & $35 \%$ \\
Total & 72 & $100 \%$ \\
\hline
\end{tabular}

Tabel 2 menunjukkan bahwa mayoritas responden memiliki pengetahuan yang cukup (46\%).

Tabel 3. Distribusi Frekuensi Efikasi Diri

\begin{tabular}{ccc}
\hline Efikasi diri & Frekuensi & Prosentase (\%) \\
\hline Rendah & 0 & $0 \%$ \\
Cukup & 27 & $37 \%$ \\
Tinggi & 45 & $63 \%$ \\
Total & 72 & $100 \%$ \\
\hline
\end{tabular}

Tabel 3 menunjukkan bahwa mayoritas responden memiliki efikasi diri yang tinggi (63\%).

Tabel 4. Tabel hubungan pengetahuan dengan efikasi diri

\begin{tabular}{llclc}
\hline & \multicolumn{2}{c}{ Pengetahuan } & Efikasi Diri \\
& $\mathrm{N}$ & $\%$ & $\mathrm{~N}$ & $\%$ \\
\cline { 2 - 5 } Kurang & 7 & 50 & 7 & 50 \\
Cukup & 18 & 55 & 15 & 45 \\
Baik & 2 & 8 & 23 & 92 \\
Total & 27 & 37 & 45 & 63 \\
\hline
\end{tabular}

Tabel 4 menunjukkan responden dengan pengetahuan kurang diperoleh efikasi diri cukup dengan persentase $50 \%$ dan efikasi diri tinggi $50 \%$. Sedangkan pengetahuan cukup diperoleh efikasi diri cukup dengan presentase $55 \%$ dan efikasi diri tinggi $45 \%$ kemudian dari pengetahuan baik diperoleh efikasi diri cukup dengan persentase $8 \%$ dan efikasi diri tinggi $92 \%$.

Tabel 5. Hasil analisis hubungan pengetahuan dengan efikasi diri

\begin{tabular}{lcc}
\hline \multicolumn{1}{c}{ Hubungan } & $\mathbf{p}$ & $\boldsymbol{\alpha}$ \\
\hline $\begin{array}{l}\text { Pengetahuan dengan efikasi } \\
\text { diri }\end{array}$ & 0,001 & 0,05 \\
\hline
\end{tabular}

Tabel 5 menunjukkan nilai p 0,001 $<\alpha=0,05$ yang menunjukkan bahwa ada hubungan antara pengetahuan dengan efikasi diri penderita TB paru di BBKPM Surakarta. Nilai koefisien korelasi Spearman sebesar 0,381 menunjukkan nilai korelasi positif dan searah dengan kekuatan korelasi rendah. 


\section{PEMBAHASAN}

\section{Karakteristik Responden}

Hasil analisis karakteristik responden menunjukkan bahwa sampel yang diteliti pada penderita TB di BBKPM Surakarta mayoritas adalahberjenis kelamin laki-laki. Hal ini sejalan dengan penelitian Rukmini (2011) didapatkan bahwa penderita TB paru pada responden laki-laki lebih besar dibandingkan responden perempuan yaitu sebesar 61,3\%. Hiswani (2009) menyatakan bahwa pada jenis kelamin laki-laki penyakit ini lebih tinggi hal ini disebabkan karena rata-rata laki-laki merokok sehingga dapat menurunkan sistem pertahanan tubuh, sehingga lebih mudah untuk terpapar dengan agent penyebab TB paru. Hal ini terbukti dari wawancara peneliti dengan 40 responden laki- laki, terdapat 35 orang menyatakan bahwa mereka memiliki riwayat merokok.

Berdasarkan hasil penelitian tabel 1 sebagian besar umur responden penelitian adalah $<55$ tahun. Hal ini sejalan dengan penelitian Helper (2010) bahwa penyakit TB paru paling sering ditemukan pada usia produktif yaitu usia 15-55 tahun. Demikian penelitian yang dilakukan oleh Rikha, Arie \& Dwi (2012) di Semarang menunjukkan bahwa umur 15-55 tahun mempunyai resiko terkena TB Paru sebesar 0,667 kali lebih besar dibandingkan umur $>55$ tahun. Menurut pertiwi (2012) penderita TB paru banyak diusia produktif disebabkan pada usia produktif akan sangat mudah tertular penyakit TB paru karena usia tersebut banyak berinteraksi dan bersosialisasi dengan orang lain atau lingkungan sekitar, sehingga dari mobilitas yang tinggi memungkinkan terjadi penularan TB paru.

Berdasarkan pendidikan responden sebagian besar adalah SD. Hal ini sesuai dengan temuan Rukmini (2011) bahwa tingkat pendidikan rendah, angka kejadian TB Paru lebih tinggi (57,3\%) bila dibandingkan dengan pendidikan tinggi 7,8\%. Hal ini sesuai dengan hasil Riskesdas 2007, bahwa prevalensi TB paru empat kali lebih tinggi pada pendidikan rendah dibandingkan dengan pendidikan tinggi. Departemen Kesehatan Republik Indonesia tahun 2009 menyatakan bahwa kondisi pendidikan merupakan salah satu indikator yang kerap ditelaah untuk mengukur tingkat pembangunan manusia suatu negara karena melalui pengetahuan serta pendidikan berkontribusi terhadap perilaku kesehatan. Pengetahuan yang dipengaruhi oleh tingkat pendidikan adalah salah satu faktor pencetus yang dapat berperan mempengaruhi keputusan seseorang untuk berprilaku sehat.

Berdasarkan karakteristik pekerjaan responden, sebagian besar bekerja sebagai wiraswasta. Hal ini sejalan dengan penelitian yang dilakukan oleh Puspitasari (2014) bahwa pekerjaan terbanyak adalah wiraswasta yakni sebesar 36,5\%. Menurut Pertiwi (2012) pekerjaan wiraswasta sangat rentan terkena TB karena disebabkan oleh lingkungan pekerjaan, sehingga terlalu sering berinteraksi dengan orang lain dapat mempengaruhi tingkat penularan akibat adanya kontak dengan orang yang menderita TB.

Lama responden menjalani pengobatan di BBKPM Surakarta yaitu sebagian besar 3-6 bulan. Sedangkan menurut Kementrian Kesehatan Tahun 2010 Pengobatan TB paru dilakukan selama enam sampai sembilan bulan. Adapun faktor-faktor yang berkontribusi terhadap pengobatan menurut Erawatyningsih (2009) yakni riwayat pengobatan, efek samping obat, pasien, obat, program nasional TB, terapi yang tidak adekuat, resistensi terhadap OAT, motivasi penderita yang rendah, jarak fasilitas kesehatan dari rumah pasien, jenuh dalam pengobatan dan biaya selama pengobatan.

Selanjutnya karakteristik responden tentang pengobatan TB menunjukkan bahwa sebagian besar responden tidak pernah mendapatkan informasi pengobatan TB paru. Menurut Aditama \& Aris (2013) dalam mencapai kesembuhan maka sangat penting untuk penderita TB paru memiliki pengetahuan tentang penyakitnya. Selama menderita TB responden sebagian besar tidak mengalami stress atau kecemasan. Menurut Lustman dalam Wu Tahun 2007 menyatakan bahwa responden yang tidak mengalami stress atau depresi berarti memiliki keyakinan untuk memotivasi diri sendiri dan berprilaku sesuai dengan tujuan yang diharapkan, sebaliknya dengan adanya stress atau depresi merupakan faktor internal yang dapat berkontribusi terhadap penurunan fungsi fisik dan mental yang menyebabkan pasien kehilangan motivasi untuk melakukan perawatan diri harian maupun pengobatan dan beresiko terjadi komplikasi lebih lanjut terhadap penyakitnya.

Sebagian besar responden mengetahui terdapat orang lain atau saudara yang mengalami keberhasilan dalam pengobatan dan responden juga sebagian besar tidak pernah mengetahui yang 
tidak berhasil terhadap pengobatan TB paru. Menurut Bandura dalam Hamidah (2011) pengalaman keberhasilan orang lain yang memiliki kesamaan dengan individu seperti keberhasilan dalam pengobatan TB paru, maka akan meningkatkan efikasi diri orang tersebut untuk mencapai kesembuhan.

\section{Pengetahuan}

Berdasarkan hasil penelitian menunjukkan bahwa sebagian besar responden memiliki pengetahuan yang cukup. Adapun tingkat pengetahuan dipengaruhi oleh umur, pendidikan, pekerjaan, faktor lingkungan dan sosial budaya (Notoatmodjo, 2010). Pengetahuan merupakan hasil tahu, dan hal ini bisa terjadi setelah orang melakukan pengamatan. Pengindraan terhadap suatu objek yang telah dilihatnya. Pengetahuan merupakan domain yang mendasari terbentuknya tindakan seseorang (ovent behavior). Sebagian besar pengetahuan dapat diperoleh dari mata dan telinga. Apabila seseorang semakin cukup umur, maka akan lebih matang dalam berfikir dan bekerja (Wawan \& Dewi, 2010).

Sebagian besar responden berpengetahuan cukup tentang penyakit TB paru dalam hal ini dibuktikan dari pasien cukup mengerti tentang pengertian, penyebab penularan, tanda dan gejala, pencegahan, pengobatan, Pengawas Menelan Obat (PMO), pemantauan pengobatan, tatalaksana pengobatan dan efek samping obat. Adapun hal ini didukung sebagaimana dari kuesioner bahwa penderita mendapat informasi tentang TB paru sebesar 38\% dari petugas kesehatan yakni berupa mendengarkan pengarahan yang diberikan oleh petugas kesehatan baik dokter maupun perawat saat mereka melakukan kontrol pengobatan atau saat konseling TB paru dan $5 \%$ dari media lain yang terdapat dilingkungan mereka, seperti koran/majalah, internet, dari tetangga maupun keluarga dan dari poster-poster yang terpasang di dinding-dinding Poliklinik TB BBKPM Surakarta.

\section{Efikasi Diri}

Berdasarkan hasil penelitian dari 72 responden menunjukkan bahwa tidak ada responden yang memiliki efikasi diri rendah hal ini dikarenakan pasien memiliki keyakinan untuk sembuh sehingga mereka datang untuk berobat, kemudian hasil lain didapatkan bahwa sebagian besar responden mempunyai efikasi diri tinggi. Efikasi diri yang tinggi dalam penelitian ini terdiri dari pasien mematuhi program pengobatan selama enam sampai sembilan bulan, menjaga kebersihan lingkungan, mematuhi PMO dengan tidak lupa minum obat tepat waktu, bisa menyesuaikan diri dengan efek samping OAT, minum obat benar dosis dan benar waktu, melakukan pemeriksaan dahak untuk mengetahui perkembangan penyakit, melakukan istirahat yang cukup, dan memeriksakan diri ke pelayanan kesehatan jika ada keluhan yang memperberat penyakit.

Hasil dalam penelitian ini sejalan dengan penelitian yang dilakukan oleh Hendiani, Sakti \& Widiyanti (2013), yang menunjukkan bahwa rata-rata penderita TB memiliki efikasi diri yang tinggi sebesar $56,8 \%$. Hal ini disebabkan oleh responden ingin sembuh dari penyakit TB sehingga mematuhi semua nasehat petugas kesehatan, berbagai usaha dilakukan untuk sembuh, seperti meminum vitamin, menghindari asap rokok dan menjaga kebersihan rumah.

Menurut Bandura dalam Masraroh (2012) proses terbentuknya efikasi diri salah satunya dari kognitif atau pengetahuan. Dalam hal ini tindakan yang dilakukan seseorang yang berasal dari pikirannya. Kemudian pemikiran tersebut memberi arahan bagi tindakan yang dilakukan. Jika semakin tinggi pengetahuan, tingkat pendidikan, dan pekerjaan yang dimiliki akan memberikan konstribusi terhadap terbentuknya efikasi diri yang tinggi dan efikasi diri yang tinggi tidak dapat lepas dari adanya faktor-faktor yang mempengaruhi seperti pengalaman individu sebelumnya, pengalaman orang lain yang sama, persuasi sosial maupun keadaan fisiologis dan emosional.

\section{Hubungan antara Pengetahuan dengan Efikasi Diri}

Berdasarkan dari hasil analisis deskriptif kategori efikasi diri dan pengetahuan menunjukkan bahwa rata-rata penderita TB Paru memiliki efikasi diri tinggi dengan pengetahuan yang cukup, hal ini ditandai oleh penderita TB Paru memiliki keyakinan yang kuat terhadap kemampuan dengan 
mengerahkan segala usaha agar dapat sembuh. Responden berkeinginan untuk sembuh dari penyakit TB Paru sehingga responden mematuhi program pengobatan selama enam bulan. Responden tetap kontrol tepat waktu bila obat habis, responden tetap minum obat, walaupun sebagian responden merasa efek samping dari OAT yaitu gatal-gatal, pusing dan mual. Responden menyatakan tetap ingin meminum obat sampai dinyatakan benar-benar sembuh oleh dokter.

Berbagai usaha dilakukan responden untuk bisa sembuh dari penyakit TB Paru, seperti memakan makan yang bergizi, menjaga kebersihan lingkungan, dan istirahat yang cukup. Adapun lainnya dari hasil analisis menunjukkan bahwa ada 7 responden yang berpengetahuan kurang tapi efikasi dirinya cukup, hal ini dikarenakan pasien tidak memiliki informasi yang cukup mengenai penyakit TB paru sehingga pasien kurang paham tentang penyakit TB paru dan dari hal itu pasien memiliki keyakinan yang cukup terhadap kesembuhan, dan 7 responden yang berpengetahuan kurang tapi efikasi dirinya tinggi, hal ini dikarenakan pasien selalu mendapat dukungan dari keluarga untuk tetap kontrol jika obat habis serta pasien juga sudah merasakan tingkat kesehatan yang lebih membaik selama menjalani pengobatan, kemudian ditemukan 2 responden yang berpengetahuan baik dan efikasi dirinya cukup, hal ini dikarenakan pasien mengalami efek samping obat seperti pusing dan mual yang membuat aktivitas pasien terganggu.

Hasil penelitian ini diketahui bahwa pengetahuan adalah salah satu faktor dari proses terbentuknya efikasi diri. Pengetahuan sebagai dasar individu untuk menentukan sikap dan perilakunya. Pengetahuan sendiri dipengaruhi oleh pendidikan, pekerjaan, umur, pengalaman, dan informasi. Pemberian informasi yang mendalam oleh petugas kesehatan tentang penyakit TB paru sangat penting dilakukan agar pengetahuan responden meningkat. Hasil penelitian tentang pengetahuan responden di BBKPM Surakarta, rata-rata berpengetahuan cukup. Kondisi tersebut diperkuat oleh beberapa fakta di lapangan. Berdasarkan hasil wawancara setelah penelitian dengan responden bahwa mereka cukup mengetahui tentang penyakit TB meliputi cara penularan, tanda dan gejala, penatalaksanaan pengobatan, pencegahan penularan dan mereka juga yakin untuk sembuh.

Hasil penelitian ini sesuai dengan hasil penelitian-penelitian sebelumnya. Hasil penelitian Prabandari (2014) membuktikan bahwa semakin baik pengetahuan maka semakin baik motivasi seseorang melakukan pengobatan, sedangkan penelitian lain yang dilakukan oleh Novitasari (2015) menunjukkan terdapat hubungan yang signifikan antara pengetahuan dengan kepatuhan menjalankan diit pada penderita DM di Kelurahan Gayam kecamatan Sukoharjo dimana dalam hal ini semakin baik pengetahuan penderita DM tentang penyakit DM maka semakin patuh dalam menjalankan diit DM.

Hasil uji hipotesis penelitian diperoleh nilai $\mathrm{p}=0,001<\alpha=0,05$. hubungan antara pengetahuan dengan efikasi diri penderita TB paru di BBKPM Surakarta bermakna. Nilai korelasi Spearman 0,381 menunjukkan korelasi searah atau positif dengan kekuatan korelasi rendah. Berdasarkan hasil analisis tersebut menunjukkan bahwa pengetahuan memberi sumbangan terhadap variabel efikasi diri pada penderita TB Paru di BBKPM Surakarta, sedangkan selain pengetahuan ditentukan oleh faktor lain.

Faktor lain yang mempengaruhi efikasi diri adalah adanya pengalaman keberhasilan individu, pada penelitian ini pengalaman individu mengalami seperti kasus drop out, kasus kambuh, kasus gagal pengobatan telah dieksklusi guna meminimalisir variabel perancu. Pengalaman mengetahui orang lain yang berhasil pada pengobatan TB dalam penelitian ini sebesar $57 \%$ sisanya tidak mengetahui, sedangkan pengalaman mengetahui orang lain yang tidak berhasil pengobatan $13 \%$ sisanya tidak mengetahui, hal ini akan mempengaruhi keyakinan yang dimiliki penderita TB paru, adapun pernyataan dari penderita bahwa mereka yakin untuk sembuh karena mereka sudah sering mengetahui orang lain yang berhasil pada pengobatan. Selain itu kondisi fisik dan psikologis juga mempengaruhi keyakinan yang dimiliki, seperti kondisi fisik yang lebih baik yang dirasakan setelah menjalani pengobatan, serta keadaan emosi dapat mempengaruhi penilaian seseorang terhadap keyakinan dirinya dan pada penelitian ini responden yang cemas selama pengobatan hanya $24 \%$ dan mereka menyatakan kalau cemasnya karena pengobatannya yang lama dan takut nantinya tidak bisa sembuh. 


\section{KESIMPULAN}

Berdasarkan penelitian yang telah dilakukan, dapat ditarik kesimpulan bahwa mayoritas Mayoritas responden penderita TB paru di BBKPM Surakarta menunjukkan bahwa sebagian besar responden adalah laki-laki, berusia $<55$ tahun, berpendidikan SD, pekerjaan wiraswasta, lama pengobatan TB 3-6 bulan, tidak mendapat informasi tentang TB paru, tidak mengalami stress atau kecemasan selama pengobatan, pernah mengetahui yang berhasil pada pengobatan TB paru serta tidak pernah mengetahui yang tidak berhasil pada pengobatan TB paru. Tingkat pengetahuan penderita TB paru tentang penyakitnya di BBKPM surakarta sebagian besar berpengetahuan cukup. Efikasi diri penderita TB paru di BBKPM Surakarta mayoritas termasuk kategori efikasi diri tinggi. Ada hubungan yang signifikan antara tingkat pengetahuan dengan efikasi diri penderita TB paru di BBKPM Surakarta.

Sesuai hasil penelitian maka penderita TB paru diharapkan mampu mempertahankan efikasi diri yang dimiliki yaitu dengan cara selalu berusaha untuk mencapai kesembuhan. Keluarga dapat memberikan dukungan pada penderita TB paru melalui pemberian informasi tentang penyakitnya dan membantu selama proses pengobatan sehingga dapat memotivasi penderita untuk melakukan pengobatan sampai selesai yaitu 6-9 bulan. Petugas Kesehatan diharapkan dapat memberikan konseling TB kepada pasien maupun PMO dalam hal penularan, pencegahan dan pengobatan agar penderita dan PMO mengetahui serta memahami penyakit TB paru. persuasi sosial yang diberikan oleh petugas kesehatan berupa konseling dapat meningkatkan efikasi diri penderita dari segi pemahaman dan pengetahuan denganmenggunakan bahasa yang dapat dipahami oleh pasien. Hasil penelitian ini dapat menambah ilmu pengetahuan untuk peneliti lain serta dapat menjadi bahan referensi untuk melakukan penelitian sejenis karena pada dasarnya masih terdapat faktor-faktor lain yang berkaitan dengan efikasi diri penderita TB paru untuk mencapai kesembuhan, misalnya sikap maupun dukungan keluarga.

\section{DAFTAR PUSTAKA}

Aditama, H. P.,\& Aris, A. (2013). Hubungan Pengetahuan dan Motivasi Pasien TBC (Tuberkulosis) dengan Kepatuhan Berobat Pasien TBC yang Berobat di UPT Puskesmas Mantup Kabupaten Lamongan. Surya Vol.02, No.XV, Agust 2013

Anugerah, D. (2007). Hubungan Tingkat Pengetahuan dan Sikap Penderita TB Paru dengan Kepatuhan Minum Obat di Wilayah Kerja Puskesmas Jatibarang Kecamatan Jatibarang Kabupaten Indramayu (Doctoral dissertation, Diponegoro University).

Badan Penelitian dan Pengembangan Kesehatan Departemen Kesehatan RI (2007). Riset Kesehatan Dasar 2007. Jakarta

Departemen Kesehatan Republik Indonesia. (2007). Pedoman Penanggulangan Tuberkulosis (TB). Jakarta. Departemen Kesehatan RI

Departemen Kesehatan Republik Indonesia. (2009). Buku Saku Kader Program Penanggulangan TB. Jakarta.

Dinas Kesehatan Provinsi Jawa Tengah. (2013). Buku Profil Kesehatan Provinsi Jawa Tengah Tahun 2012. Dinas Kesehatan Provinsi Jawa Tengah. Semarang.

Erawatyningsih, E. (2009). Faktor- Faktor yang Mempengaruhi Ketidakpatuhan PengobatanTB. Di peroleh dari http://www.google.com/urlFin donesia.digitaljournals.org\% m=bv.71198958, d.dGc.2009 Tanggal 15 November 2015.

Hamidah, H. (2011). Pengaruh self efficacy Terhadap Kemampuan Komunikasi Matematik. Yogyakarta State University.

Helper Sahat P Manalu. (2010). Faktor-Faktor yang Mempengaruhi Kejadian TB Paru Dan Upaya Penanggulangannya. Jurnal Ekologi Kesehatan Vol. 9 No. 4, Desember 2010 : 1340-1346

Hendiani, N., Sakti, H., \& Widiyanti, G. (2013).Hubungan Antara Persepsi Dukungan Keluarga Sebagai Pengawas Minum Obat dan Efikasi Diri Penderita Tuberkulosis di BKPM Semarang. Jurnal Psikologi Undip, 12(1), 1-10.

Hiswani. (2009). Tuberkulosis merupakan Penyakit Infeksi yang menjadi Masalah Kesehatan Masyarakat. http://library.usu.ac.id/downlo ad/from:hiswani6.pdf2009 diperoleh 16 November 
2015

Imron, M. (2010). Metodologi Penelitian Bidang Kesehatan.Sagung Seto: Jakarta

Kementrian Kesehatan Republik Indonesia. (2010). Pedoman nasional penanggulangan tuberkulosis. Jakarta.

Masraroh, L. (2012).Efektivitas bimbingan kelompok Tehnik Modeling untuk Meningkatkan Self Efficacy Akademik Siswa Studi Eksperimen Kuasi di Kelas X Sekolah Menengah Atas Laboratorium Unversitas Pendidikan Indonesia Bandung(Doctoral Dissertation, Universitas Pendidikan Indonesia).

Naga, S. S. (2013). Buku Panduan Lengkap Ilmu Penyakit Dalam. Jogjakarta: Diva Press.

Notoatmodjo, S. (2010). Metodologi Penelitian Kesehatan. Jakarta: Rineka Cipta

Notoatmodjo, S. (2014). Ilmu Perilaku Kesehatan. Jakarta: Rineka Cipta.

Novel, S. S. (2011). Ensiklopedi Penyakit Menular dan Infeksi. Jakarta : Familia.

Novitasari, R (2015). Hubungan antara Pengetahuan dan Sikap dengan Kepatuhan Diit Diabetes Mielitus (DM) pada Lanjut Usia (Lansia) di Kelurahan Gayam Kec. Sukoharjo Jurnal Keperawatan Univ.Muhammadiyah Surakarta 2015.

Rikha N P, M.Arie W, Dwi S. (2012). Hubungan Antara Karakteristik Individu, Praktik Hygiene dan Sanitasi Lingkungan Dengan Kejadian Tuberculosis Di Kecamatan Semarang Utara Tahun 2011. Jurnal Kesehatan Masyarakat, Volume 1, Nomor 2, Tahun 2012, Halaman 435 - 445

Rukmini. (2011). Faktor-faktor yang Berpengaruh Terhadap Kejadian TB Paru Dewasa di Indonesia (Analisis Data Riset Kesehatan Dasar Tahun 2010). Buletin Penelitian Sistem Kesehatan - Vol. 14 No. 4 Oktober 2011: 320-331.

Pertiwi R, Wuryanto MA, \& Sutiningsih. (2012). Hubungan Antara Karakteristik Individu, Praktik Hygiene dan Sanitasi Lingkungan dengan Kejadian Tuberkulosis Di Kecamatan Semarang Utara Tahun 2011. Semarang: Jurnal Kesehatan Masyarakat, 2012.

Prabandari, I.(2014). Hubungan tingkat pengetahuan dengan motivasi untuk memeriksakan diri pasien hipertensi pada Lanjut Usia di Puskesmas Kerjo Karanganyar. Jurnal Keperawatan Univ.Muhammadiyah Surakarta April 2014.

Pusat data dan Informasi Kemenkes RI. (2015). TuberkulosisTemukan Obati Sampai Sembuh. Pusadatin. Jakarta.

Puspitasari, P.(2014). Profil Pasien Tuberkulosis Paru di Poliklinik Paru RSUP Prof. Dr. R.D Kandou Manado. Jurnal Fakultas Kedokteran Univ. Sam Ratulangi Tahun 2014 Manado.

Wawan A dan Dewi M. (2010). Teori dan Pengukuran Pengetahuan, Sikap, dan Perilaku Manusia. Yogyakarta: Nuha Medika

Widoyono. (2011). Penyakit Tropis Epidemiologi, penularan, pencegahan dan pemberantasannya. Jakarta : Erlangga.

World Health Organitations. (2010). WHO Report 2010 Global Tuberculosis Control. WHO Library Catalouging In Publication Data. ISBN 9789241564069

Wu, S.F.V. (2007). Effectiveness of self management for person with type 2 diabetes following the implementation of a self- efficacy enhancing intervention program in taiwan Queensland: Queensland University of Tecnology (Thesis master, Queensland University of Tecnology) diperoleh dari http://eprints.qut.edu.au/1638 5/1/1/Shu- Fang_Wu_Thesis.pdf, Tanggal 16 November 2015. 